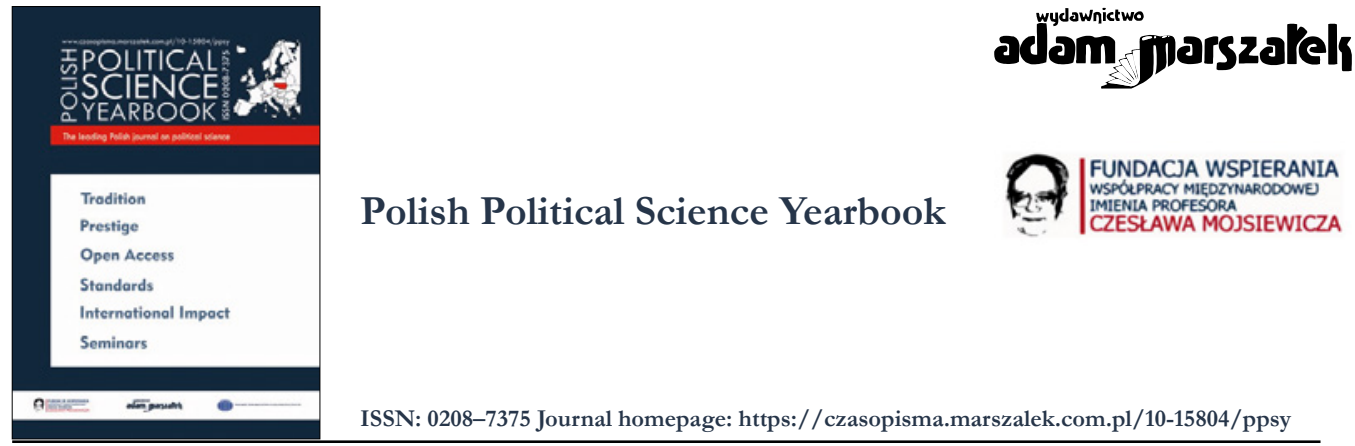

\title{
Military Security of Poland - From Theory to Practice
}

\section{Grzegorz Sobolewski}

ORCID: 0000-0002-4484-450X

To cite this article please include the following information:

- Journal title: Polish Political Science Yearbook

- Volume number: 50

- Year of publication: 2021

- Published ahead-of-print

Example styles:

[APA Style]: Sobolewski, G. (2021). Military Security of Poland - From Theory to Practice. Polish Political Science Yearbook, 50(issue number), pages. https://doi.org/10.15804/ppsy202150

[Chicago Style]: Grzegorz Sobolewski, "Military Security of Poland - From Theory to Practice" Polish Political Science Yearbook 50, no. [issue number] (2021).

To link to this article: https://doi.org/10.15804/ppsy202150

Published ahead-of-print

曲 Final submission: 2 November 2021

Published online: 2 November 2021

Printed issue: 2021

Submit your article to PPSY 


\title{
Grzegorz Sobolewski
}

Main School of Fire Service

Institute of Internal Security

ORCID: 0000-0002-4484-450X

\section{Military Security of Poland - From Theory to Practice}

\begin{abstract}
National and international security remains a fascinating area of scientific research. Studies of phenomena and processes in military security suggest that we are witnessing great and intense changes. In their analyses of the modern security environment, both NATO and the EU wish to accommodate the existing conditions. Poland also has been affected by that process. The security policy should be based on the main assumption that Poland is a sovereign security entity, able to define its national interests and strategic objectives autonomously. However, the foundations of our security are assured by membership in the EU and NATO, good relations in the region, a strategic alliance with the USA, and an internal defense mechanism. The needs of the state and the society for national security arise from a dynamic rate of changes in challenges and hazards. The Author intends to combine theory with practice that is implemented in favor of the military security of Poland. First of all, the essence of military security is presented from theoretical and utilitarian viewpoints. The subsequent parts of the paper present research results related to the identification of contemporary challenges and hazards to the military security of Poland. This approach provided an opportunity to outline assumptions of policy and strategy underlying military security in current international security conditions.
\end{abstract}

Keywords: national and international security, military security, military challenges and threats, state defense system, military potential, security strategy

\section{Introduction}

Due to the complexity of contemporary military security in a national and international dimension, there is a constant need for improving actions aimed at its assurance. Very often, challenges will come up that create problems for security, which have to be faced by states to ensure the security of their citizens. People live and will continue to live in an environment full of potential challenges and hazards that tend to change their nature, mainly depending on ongoing civilization development processes. Experience gained in the past years shows 
there is invariably a strong probability that the functioning balance would be disrupted and that due to challenges and hazards, a situation of a military crisis would arise.

Consequently, the principal objective of the conducted research is the identification of principal challenges and hazards to the military security of Poland and the presentation of key assumptions of security in current conditions.

The main research problem assumed for the needs of the executed studies has been formulated as the following question: What should be Poland's main assumption of military security in the current conditions considering contemporary military challenges and hazards?

Presently the military security of Poland is being affected first of all by processes and phenomena that occur in its surroundings - in the regional, European, and Euro-Atlantic community dimension. Watching national and international security changes allows a presumption that contemporary challenges and hazards arise from complex and interconnected political, economic, and social processes of a national and international range. Hence the projection and analysis of hazards become one of the most important areas of cognition, as they are strictly related to security, and to a certain extent, they may also be comprehended as its antonym. In simple terms, it may be assumed that the essence of security assurance is expressed in the ability to shape that security by measures oriented toward making use of opportunities, taking up challenges, minimizing risk, and eliminating external and internal hazards. Consequently, the military security of Poland may be perceived as the capability of the state to assure vital national state interests, possibilities of implementing its political goals by adopting an appropriate security policy, good international cooperation under the NATO Alliance, the EU, and the strategic partners (USA, France, Germany) and building own defense and protection abilities.

\section{The Essence of Military Security}

Analyzing the interpretation of security in the past centuries, one can say it has constantly been evolving, but the intensification of this process falls on the turn of the $20^{\text {th }}$ and $21^{\text {st }}$ centuries. At that time, it was highly dynamic and expressive. The main factors (determinants) affecting transformations and the current perception of security comprised, in the first place, changes taking place in the international environment, but there were also changes to the nature of hazards. The traditional order of the world, existing for centuries based on a division into political and military blocks and superpowers, which to date kept affecting the security paradigm, is already a thing of the past. Due to the democratization of countries, the openness of the borders, globalization progressing in all dimensions, non-military hazards gain crucial importance for security beside classical military threats and the combination of their different forms into so-called hybrid risks. For this reason, a prediction and an analysis of hazards form one of the most important areas of cognition because they are strictly related to security, and to a certain extent, may be considered even its antonym. 
Literature of the analyzed topic provides numerous different types of divisions and typology of security in a breakdown by subject and object, area or scope, or internal or external security. Appropriately to the main fields and sectors of state functioning and human activity, we may distinguish political security, military security, social security (Marszałek-Kawa \& Plecka,2017), economic security, information security, cultural security, ecological security, etc.

Military security is an integral part of national security understood as the essential value, national need, and priority objective of the operation of the state, individuals, and social groups. It is a process including diverse means, guaranteeing lasting national existence and growth (of the state) free of disruptions, including protection and defense of the state as a political institution, individuals, the entire society, their goods, and natural environment from potential hazards, which significantly limit its functioning or are harmful to goods that are subject to special protection (Kitler, 2011, p. 31; Marszałek-Kawa \& Plecka, 2019).

Security in the practical sense may be perceived as activities of the given entity, which strive to assure possibilities of survival, development, and freedom of implementation of one's interests in specific conditions by making use of favorable circumstances (opportunities), taking up challenges, minimizing risk and counteracting (preventing and opposing) all types of hazards for the given entity and its interests (Koziej, 2008, p. 7). It suggests the correctness of the interpretation of the military security, which views it as an ability to ensure vital state interests of the state, implementation of its political goals, and of guaranteeing independence to own institutions and citizens inhabiting the area within its borders, sovereignty and possibility of self-determination and solving of own problems with the use of the existing political system. In most cases, that capability will have the nature of a military force and will be oriented against the military aggression of an external factor (Majchrzak, 2015, p. 26).

In the general context, the military security of the state will be perceived as a certain state of awareness, in which the existent, projected, or feasible level of military threats do not give rise to concern for the ability to preserve the recognized values, implementation of fundamental interests and achievement of strategic goals thanks to the conviction about the effectiveness of implemented and planned own measures and those of other entities, as well as thanks to the acquired defense and protection abilities (BBN, 2012, p. 40).

A classical interpretation of military security is offered by Słownik terminów z zakresu bezpieczeństwa [Dictionary of terms related to security], where the security has been defined as a field of state security related to the possibility of opposing all kinds of military threats, by way of maintaining appropriately organized and equipped armed forces, military alliances, as well as having at disposal strategic concepts for their usage, appropriately to the given situation (Pawłowski et al., 2020, p. 29). The complete contemporary interpretation of military security is presented by B. Balcerowicz, who defines it as a process that covers diverse measures and diverse means aimed at counteracting external and internal hazards, which may lead to the threat of using military forces to violate the territory and limit the 
sovereignty of the state, maintaining the ability to oppose the use of military force. At the same time, it is a state achieved due to organized defense against such hazards (Balcerowicz, n.d., p. 3; Marszałek-Kawa \& Plecka, 2019).

Each sovereign country, including Poland, strives to assure its citizens of the appropriate internal and external security level to create undisturbed and effective functioning conditions. The contemporary security environment is increasingly complex and uncertain. There is an uptrend in political, military, economic, and social interactions on the national, regional, and global scale. It significantly impacts the strategy and main directions of transformations in the national security system (Strategia..., 2020, p. 5).

Given its national identity, based on historical experience and contemporary needs, the Republic of Poland considers military security as one of the fundamental values that reflect the most important state interests, in line with the Constitution of the Republic of Poland, as an ability to assure independence and inviolability of its territory (Marszałek-Kawa et al., 2014).

In conclusion, we may assume that currently, the military security of Poland should be comprehended as the implementation of a process aimed at guaranteeing the ability to protect and defending vital national interests (mainly sovereignty, independence, and territoriality) by way of adopting the appropriate security policy, good international cooperation under the NATO Alliance, the EU and strategic partners (USA, France, Germany) and expanding own protective and defense abilities. The world nowadays is not free of military threats. Quite recently, Ukraine and Georgia have become painfully aware of this, earlier on the Balkan states or countries of the Middle East. That is why each responsible country should establish conditions conducive to assuring the security of basic national interests (vital interests), such as sovereignty, independence and territorial integrity, and survival of the nation and state structures during the external threat to its security and war ${ }^{1}$. Poland's membership in NATO and the European Union constitutes a foundation of our national security. The concept of Poland's security should be based on joint measures to be undertaken with other entities of the international security environment, but just as well on the abilities of own forces and means needed to protect vital state interests in case of a military threat. Only appropriately implemented defense preparing activities of the state defense system entities can assure effective functioning of the state and efficient defense in case of an external hazard to the military security and during the war.

${ }^{1}$ Basic national interests and strategic goals of the Republic of Poland are defined in Article 5 of the Constitution of the Republic of Poland (Polish Journal of Laws/Dz.U. of 1997 No. 78, item 483). On the other hand, specific ones (appropriately to present situation and circumstances) are further defined in the valid Strategiy of National Security of the Republic of Poland. 


\section{Hazards to Military Security}

Transformations in the contemporary security environment consist of shifting the point of gravity from classical types of hazards (direct military invasion), the role of which is gradually decreasing, onto hybrid and asymmetric threats, the sources of which are also constituted by non-state entities that are difficult to identify. Appropriate planning of the international and national security policy should consider the contemporary nature of new hazards, which may be anticipated in the future.

A military hazard may be perceived as an incident or as a likelihood of occurrence of such an incident, during which vital state interests are endangered, as well as political goals, state values, and interests; in many cases, there could be a hazard of the loss of independence, sovereignty and territorial integrity (Majchrzak, 2015, pp.32-33). We may also interpret those threats as all potential or existing events (actions) resulting from the deployment of armed force against another entity (Pawłowski et al., 2020,p. 277). It indicates that a military hazard is also likely to arise if there is a considerable risk (threat) that armed (military) violence would have to be used to solve a dispute or a conflict. In the case of this type of hazard, the factor having an adverse impact would in most cases be military, but also other forms are possible - of a non-military nature (e.g., hybrid, asymmetric). Also to be borne in mind are the effects of generating such hazard, as in most cases it would create the need of responding by military state forces and means. Frequently in a situation of a military threat, the state would be functioning in a state of war. The most frequently mentioned military hazards associated with the possibility of resorting to armed violence (direct and indirect use of armed forces as a tool for achieving the political goals) comprise the following (Balcerowicz, 1997, p. 74):

- demonstration of force,

- military diversions and military blackmail,

- military blockade,

- military provocation,

- border incident,

- limited usage of armed violence means,

- armed border clash,

- armed aggression of informal groups,

- local conflict,

- conflict between countries,

- global conflict.

In the current situation, military threats are not easy to determine. The term is frequently related to the use or threat of use of means and resources of a military nature. Military threats are the ones that are most dangerous for state security. Quite frequently, their consequences have an adverse impact on the community and on specific social groups, the state's functional structure, including critical infrastructure, and the natural environment that may affect the entire country's economy. 
Analyses of present conditions in the closest surroundings of Poland in the aspect of military threats have clearly shown that Poland should never cease to keep up the ability to respond to various forms of this type of hazard. They may assume the following forms:

- hybrid war, which comprises such elements as information and psychological measures with mass-scale usage of the so-called "black propaganda", offensive measures in cyberspace, diversionary actions in various fields of state functioning, up to irregular actions;

- asymmetric hazards such as unfair fight, hitting a weak point (elements of critical infrastructure), information warfare, fight in the sphere of public opinion, the threat of usage or usage of military means, fight in cyberspace;

- the possibility of an armed conflict may not be ruled out as a tool for solving internal political or economic problems, for example, in Belarus, Russia, or Ukraine.

Russia's aspirations to be a superpower, unstable situation in Belarus and Ukraine may be used to destabilize security in Eastern Europe. As a result, it could lead to using various forms of military threats to Poland:

- military blackmail, most likely with the use of long-range missiles and perhaps even nuclear weapons distributed close to our territory (Kaliningrad Oblast and Belarus), the aim of which is to prevent Poland's equal treatment as a member of NATO and establishment of a zone of lowered security as compared to territories of "traditional" member states of the Alliance;

- demonstration of force comprising military drills close to our borders and territorial waters and temporary or permanent dislocation of units equipped with the latest cutting-edge military technology. Also not to be ruled out is constant maritime surveillance, as well as regular flights of military forces close to the territory of the Republic of Poland, including a violation of our territorial waters and airspace;

- military pressure consisting of incremental expansion of military potential in the vicinity of our borders, enforcing us to take up appropriate measures;

- military provocation or border incident having various possible political goals;

- involving Poland or the Alliance in a conflict on the point of contact of Russia's aspirations of becoming a superpower and attempt at the subordination of countries of the former Soviet Union.

Due to the continuously progressing phenomenon of globalization, we are witnessing an escalation of hazards of a hybrid nature that combine various methods and forms and different military and non-military means, the use of which allows achieving the assumed goal of the given entity. Hybrid hazards are characterized by great variability and diversity, and their tools comprise all forms, starting with false profiles in the social media, through advanced cybernetic attacks up to open use of regular actions of armed forces, as well as measures of numerous irregular entities and everything that goes between. Hybrid influence-exerting tools may be used separately or combined, depending on the type of goal and expected results. It clearly shows that combatting hybrid threats needs to be equally 
dynamic and flexible - it needs to attempt to allow for different hybrid methods of influence and must also foresee which area is to be considered a priority this time and which new tools could be used ${ }^{2}$. Hybrid actions combine many types and forms of measures meant to enable achieving the desired effect.

Apart from being highly diversified, a characteristic feature of hybrid hazards is that they are appropriately adapted to prey on specific weaknesses of selected victims. Such actions are likely to have an adverse impact in various fields of functioning of the country under attack. In most cases, it would include the economic, social, and political fields. Hybrid hazards make use of synergy created by numerous entities and operations. Further features of such actions comprise, among others, the combination of psychological operations with information measures to influence society's attitude and public opinion. Hybrid hazards may also involve irregular actions, but typical episodes of regular military actions may not be ruled out. In many cases, such actions would be long-term and variable regarding intensity and the range of impact. It may be presumed that this type of operation would continue to be an important point of focus of politics, serving both state entities and non-state actors as means to achieve their goals.

Other perilous forms of military threats include asymmetric hazards. An increasing number of states and international organizations started to become aware of the rank and importance of those hazards, particularly the possibility of their likely but also destructive impact on the state and its citizens. Diverse publications provide different definitions of asymmetry. For example, in Zagrożenia asymetryczne, Pawłowski and Gawliczek (2003, p. 18) have put forward a thesis that currently, asymmetric hazards pertain to the military and non-military fields. They comprise thinking, organization, and operation different from the opponent's, including using all types of differences in the broadly understood potential of the parties. The objective is to maximize own advantage, benefit from the opponent's weakness, gain domination over it, and have more operational freedom. A different interesting interpretation of asymmetric hazards has been outlined by Madej (2007, p. 44), who attempts to draw attention to the need of distinguishing two concepts - asymmetry of methods, technical and operational tactics from the asymmetry of hazards (challenges) concerning the entity that causes the given kind of threat. When using the term "asymmetry" to describe new hazards, it is primarily associated with unfair fights, hitting a weak point, information warfare, fights in the sphere of public opinion, a hazard of using or actual use of mass destruction weapons, and fight in cyberspace.

The object of established asymmetric hazards must not necessarily be the state; they may be oriented toward any organized group of people (political, religious, criminal, ideological, ecological, etc.) who share specific goals. In many cases, the generated hazards may be related to diverse threatened entities, many areas of state operation, specific methods and forms of

2 https://www.nato.int/docu/review/pl/articles/2018/11/23/wspolpraca-przeciwko-zagrozeniom-hybrydowym/index.html 
operation, and the nature of used means and forces. An asymmetric conflict is not limited to the battlefield, the front, or rules and does not follow any principles at all. It proceeds in a state of dispersal without maintaining geographical or chronological continuity. For example, an entity that becomes involved in asymmetric war uses all available instruments to achieve the intended goal. In other words, an asymmetric hazard requires the existence of two entities - a threatened entity and a threatening entity - between which an asymmetry of potentials, used forces, means, and methods and forms of operation, exist. The diversity of asymmetric means at the disposal of the potential opponent is considerable and might even increase in the future.

Creating a new fighting space, i.e., cyberspace, causes many countries and international organizations to perceive an urgent need to develop defense or offense abilities in cyberspace. Experts in this field agree that priority measures on a national and international level should be to secure critical telecommunication infrastructure from hazards expected from cyberspace and establish a cohesive security policy at that level. Security of the critical telecommunications infrastructure is crucial for key areas of state functioning.

A further feasible source of military threats is Russia's aspirations to become a superpower, and so the world should keep a close eye on this country. The contents of the Security Strategy of the Russian Federation clearly that the future Russia is a country that returns to the global political scene as a key player (Budzikowski, 2010, p. 162). The document's authors believe that the Russian Federation has managed to overcome its economic crisis and handled the phenomena of terrorism and separatism on its territory. It may be presumed that the current policy of Russia is oriented toward the creation of a new international order, which would protect Russia from western interference in its internal affairs and guarantee to it equal status with a superpower such as the United States. Russia's involvement in Syria was in the first place to remind the world that it is still a global player in the issue of security and weakening and even blocking western and especially American humanitarian intervention. It seems that a highly probable objective of Russian politics may be impairing (loosening of ties) of Turkey's relations with the United States, NATO, and the western community, and in a different perspective, having it a part of the new regional system of own forces. Another disquieting phenomenon is that Iran is becoming the key strategic partner of Russia in the Middle East. If we also consider the aggressive policy of the USA toward China and Russia's willingness to cooperate with its Asian neighbor, we may indeed witness the process of building a new power balance on a global scale. That, in turn, might contribute to Russia's will to go back to the superpower of the Russian Federation and regain influence in Eastern Europe. As a result of Russia partly losing influence over Ukraine (especially on the western part), in case of political changes in Belarus, the Russian Federation would not give up so easily. It would most likely do everything in its power to make this country dependent on its own politics and economy. For Europe, Russia has always been a dilemma and will certainly continue to be like that in the future. Europe may be fully safe only if there is cooperation with Russia, 
but the European security system, which includes Russia internally, is difficult to accept (Brzeziński, 2002, pp. 207-227).

It is ubiquitous for the Poles to think that upon becoming a fully pledged NATO member, Poland has been covered by a "protective umbrella" of the Alliance, and all concerns related to potential hazards to security should become invalid. This assumption is highly erroneous because, from a buffer country, we have become the eastern border of the North Atlantic Alliance and even a strategic region of NATO in the aspect of the security of the Baltic states. Contemporary measures related to the possibility of using military force, modernization of potential, its distribution in scenarios of exercises point to the fact that Russia is attempting to increase the risk of conflict in our region. The Russian Federation keeps intensely developing the offensive military potential, among others in the region of the Baltic Sea, especially in the Kaliningrad Oblast. It prepares to undertake large-scale activities and try out scenarios assuming a conflict with the North Atlantic Alliance countries. It is also a crucial region for Russia, because if hypothetically Russia would wish to occupy any of the Baltic states (on a comparable basis as has happened in Crimea), then the Suwałki isthmus ${ }^{3}$ (fig. 1) would be the only land direction from which NATO could make an intervention and grant assistance to Baltic countries in need of help (Sobolewski, 2020, p. 35).

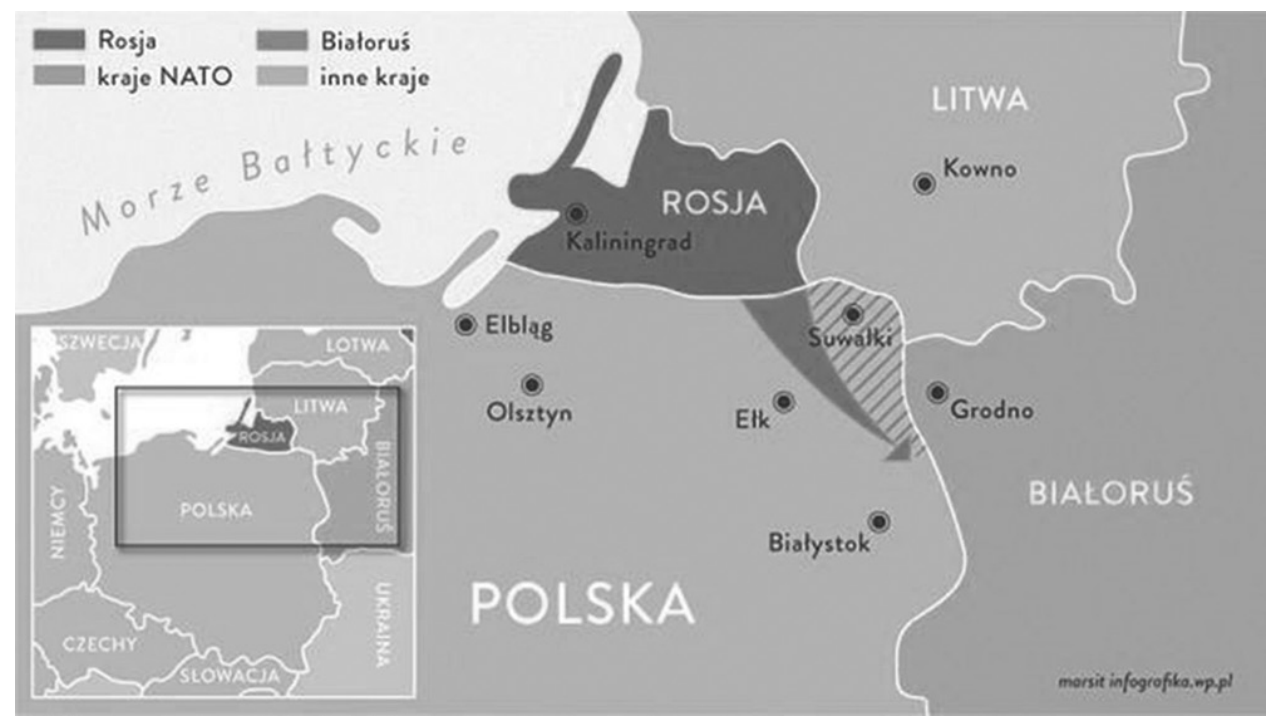

Fig. 1. Geopolitical and military importance of the Suwałki isthmus Source: http://amerbroker.pl/?go $=$ content\&action $=$ show\&id $=468$

3 The territory and border of Poland (ca. $100 \mathrm{~km}$ ) with Lithuania. A strategic NATO region given the only landside access to Baltic countries, but it also separates the territory of Russia (the Kaliningrad Oblast) from befriended Belarus. 
Since the annexation of Crimea, social and political awareness have extended to comprehension of the strategic importance of the Suwałki isthmus ${ }^{4}$. It is a region of key importance from the viewpoint of the military security for Poland, the Baltic states of NATO, and NATO itself. Greater density of NATO troops in a strategic region and on the territory of Balkan states (under the leadership of the USA, Canada, Germany, and Great Britain) is supposed to cool down the aspirations of Russia and prevent potential aggression. An attempt at the Suwalki isthmus by Russia may become a cause of a military conflict between Russia and NATO, which Russia does not seem to want for the time being. Nevertheless, a change of political conditions in the aspect of European and Asian forces balance may make this topic even more important than it is for the present.

Poland's accession to NATO puts us in the same position as other member states, and we may become an object of interest and influence by opponents of the Alliance. The form of such impact may vary, ranging from intelligence actions through information measures, terrorist actions to military operations. Despite membership in NATO and the EU, we may not entirely exclude a hazard of a military conflict in Europe. Considering military threats in the aspect of the direct intervention of NATO allied forces, the only hazard which may be ruled out (i.e., considered as unlikely) is that from Germany, the Czech Republic, and Slovakia as members of the Alliance ${ }^{5}$, yet such threat does exist from eastern countries. It may be proven by the situation in Eastern Europe, which remains unstable, the annexation of Crimea by Russia, rupture in the EU, and discussions of the future of NATO.

When predicting possible military threats, it is necessary to analyze the perspective European security system, and in the first place, potential coalitions, alliances of Russia, for example, with Belarus or similar countries. A military threat arises not only from having at disposal a given military potential. It may not be ruled out that they could use that potential to resolve the dispute in their favor in case of a conflict. An assessment of the state of potential held by countries, particularly neighboring ones, would generate a conclusion concerning the scale of the potential hazard to Poland.

${ }^{4}$ General Ben Hodges, Commander-in-Chief of the US Armed Forces in Europe has already been trying to draw attention for a long time to the fact that the so-called Suwałki Isthmus situated on the border area between Poland and Lithuania is one of the most serious sources of potential conflict in Europe. Polish experts have no illusions that if Russia decided to take over the Baltic countries or strike to the west, this region would become an ignition point of a conflict and form a highway for troops of Vladimir Putin.

5 In the past Greece and Turkey (two allies from the NATO) started a serious mutual conflict due to Cyprus. In a situation of a hazard to Greece from Turkey, the Greeks have found themselves alone. "NATO allies" have limited themselves to persuasions made to the conflicting parties. For this reason, the Swedes, Finns, Lithuanians, Danes etc. decided not to make savings on defense, although it is generally clear that their defense potential is much weaker than that of each of individual neighbours. It implies that only someone exceptionally irresponsible, ignoring the fate of our country, could insist that Poland does not need to have and to enhance its own state defense system, because the world would not ley us get hurt and that it would rush to help us in case of a hazard (Targowski, 1993, p. 57). 
Assessing typical prerequisites of security in our country, a presumption may be made that effective strengthening of the political position on the international arena (activity of the Armed Forces of the Republic of Poland under the NATO alliance, good relations with the USA, strong position in the EU), quick rate of economic growth, growth in prosperity, the inflow of foreign investments, stable macroeconomic situation, enhancement of the educational level have become directly transposed on improving Poland's internal security. However, security is not a state but a process in which certain factors affect numerous relations.

\section{Assumptions of the Policy of Military Security and Building Defense Capabilities}

If we observe the situation in national and international security, we may witness profound and intense transformations. In the era of globalization, national security may not remain merely an issue of own forces and means, which can be assigned for the purpose by aiven country. In a world of global hazards, international cooperation is a prerequisite for keeping up peace, international security, including national security. Due to the global nature and the transsectoral nature of hazards, presently, state security may not be perceived purely from the viewpoint of acting on the territory of own country in a situation of hazards. The mentioned unpredictability and ambiguity of contemporary hazards (frequently on an international, regional and global level) may give rise to a situation when the operating balance of a given country and its society would become disrupted. In a world of global hazards, security may not remain only a national level concern; instead, we should be building national security systems on pillars of our membership in NATO and the EU and several coalitions and international cooperation. Given global challenges and hazards, international cooperation has become a prerequisite for preserving peace and international security, including national security. It is because the classical division into internal and external aspects of security has long passed into oblivion. At present international and national security is no more a static phenomenon. A review of crises at the turn of the $20^{\text {th }}$ and $21^{\text {st }}$ centuries shows it is highly dynamic.

Contemporary challenges and hazards arise from complex and interrelated political, economic, and social processes of a national and international scale. The complexity of such issues as contemporary security in an international dimension gives rise to a different, global approach to its shaping. That proves the correctness of the assumptions of the Polish security ${ }^{6}$, based on membership in NATO and the European Union, and on extensive

6 The national security policy is a part of state policy, which comprises the operation of state authority bodies on the internal arena of the county as well as in the international sphere, consisting in setting objectives and national interests in security and assuring their implementation with the use of means and tools at disposal (Kitler, 2018, p. 36). 


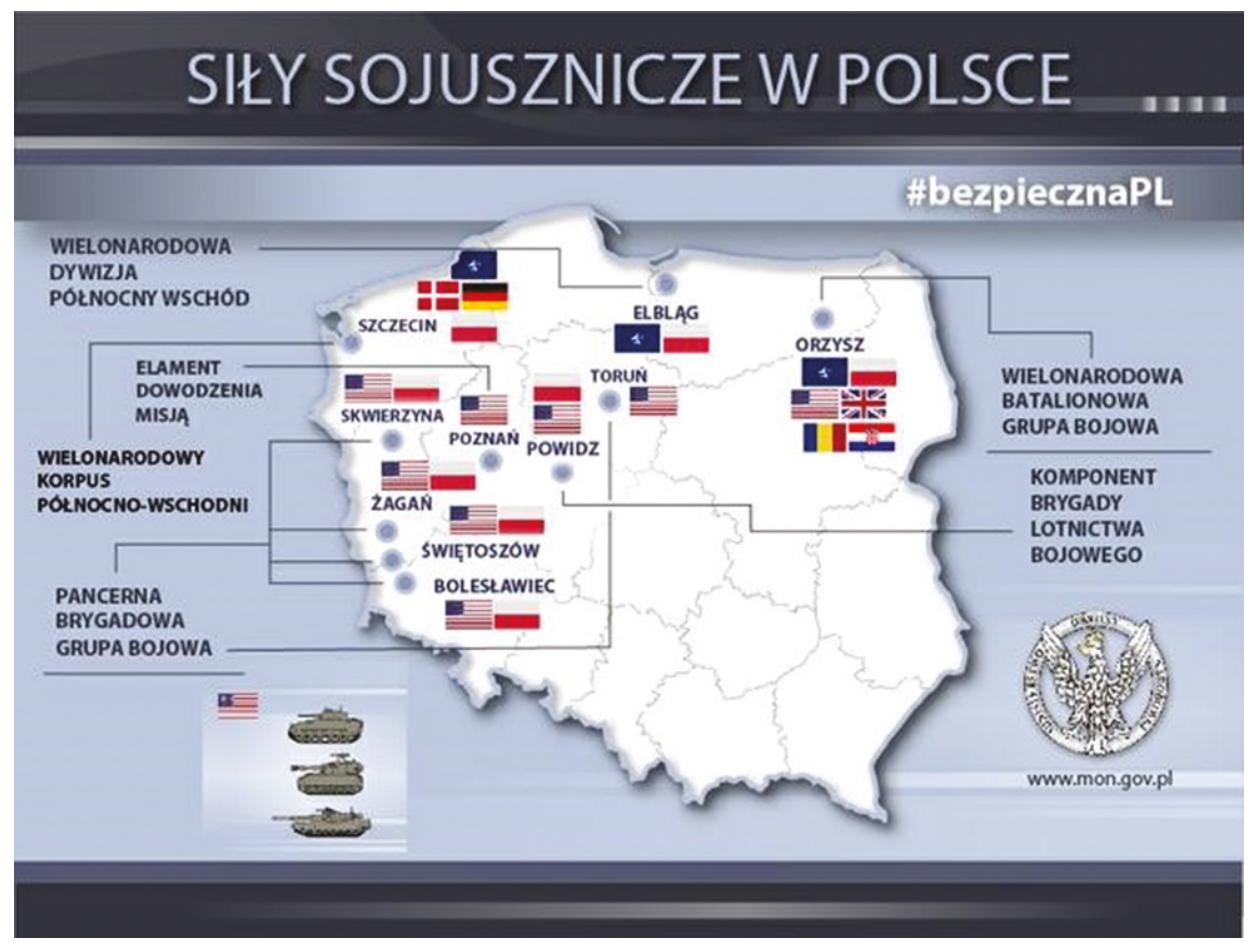

Fig. 2. Presence of NATO forces in Poland.

Source: https://archiwum2019.mon.gov.pl/sily-sojusznicze-w-polsce

cooperation with neighbors and strategic partners (e.g., the USA), which have become one of the basic guarantors of our security and our international position. The active politics of Poland, commenced at the summit in Newport at the end of 2014, after the annexation of Crimea by Russia, led to an increased presence of the NATO troops and the US army.

As a member of NATO and the European Union, having at disposal solid security guarantees, Poland has adopted directions of the security policy based on the membership in the North Atlantic Alliance and integration with the European Union and coalitions with strategic partners. Confirmation of the formulated theses may be found in the Development strategy of the national security system of the Republic of Poland 2012-2022, which defined functioning conditions of a system of national security and ways of its further development. In development assumptions of the analyzed system, considerable emphasis has been placed on the international dimension of security, with the leading role in its

The task of politics is to formulate objectives (as a function of interests) and assumptions, including limitations in their achievement. Policy tells us in the first place "what to do" while the strategy explains "how to do it", specifies the route that has to become covered from assumptions to goals, making use of means at disposal (Balcerowicz, 2010, p. 17). 
shaping assigned to the diplomatic service and the Military Forces of the Republic of Poland. Considering such an approach, the main area of interest of the new development strategy for the national security system is oriented toward external and military security. Factors enhancing the national security of Poland also include effective bilateral and multilateral cooperation; enhancing the effectiveness of international law of international institutions; strengthening control mechanisms in the field of non-proliferation of mass destruction weapons and their means of delivery; caring for the effectiveness and support for the development of the control regime for conventional armaments and disarmament as well as means for building trust and security; reducing developmental differences in the world and supporting democracy and respecting of human rights (Strategia..., 2013, p. 59).

Projected assumptions of Poland's security policy in conditions of membership in NATO and the European Union in the time horizon of the few oncoming years should comprise in the first place boosting allied solidarity, Poland's position and role in NATO the European Union by active participation in NATO operations, as well as undertaking measures aimed at assuring cohesion and effectiveness of the Common Policy of Security and Defense of the European Union, which should be compatible with the strategic concepts of NATO. Poland's functioning in structures of the North Atlantic Alliance and the European Union is a guarantee for state security, but this also poses an opportunity for multidimensional development and growth of the role of our country and is also conducive to the strengthening of its position on the international arena and the impact exerted on the international environment. Involvement of our country in the collective security system and building good relations with neighboring countries create an opportunity for the Polish security policy and therefore should be considered its priority. The only way to implement the indicated assumption would be to achieve defense and protection potential adequate for the needs and possibilities of the state and by increasing its compatibility with the potential of allies and partners from NATO and the European Union. It will also enable taking up actions aimed at assuring effective defense in the national and allied systems. There is also a need to achieve consolidation, cooperation, and further development of both organizations, further enhancing European integration and maintaining national states' identity. A rather important assumption of our security policy should also be the constant development of international cooperation and supporting allied and European aspirations of candidate countries.

A further assumption of our policy should be continuous enhancing systemic solutions for counteracting and responding to main hazards, such as terrorism ${ }^{7}$, hybrid and asymmetric hazards, and threats in cyberspace. Potentially challenges may appear, which

7 International terrorism has a significant hazard on a global scale, but also a real threat for Poland, which may be related to its involvement in stabilization or peacekeeping operations implemented by NATO or the European Union. The anticipate fight in cyberspace (disturbances in functioning of economic and financial and defense systems of Poland, the European Union and NATO) generates the need for our country to have the ability to protect own critical state security infrastructure elements. In addition - as 
- should there be no response to them - may turn into hazards. They also include all such phenomena, as a destabilization of the political system, poorly functioning economic and social mechanisms, mass violation of human rights, impoverishment of communities, dwindling water resources, degradation of the natural environment, natural disasters, growing demand for power combined with hindered access to energy resources, depleting resources of rare metals and demographic problems (Strategia..., 2020). However, an effective security policy comprises not only "negative" measures, focused on eliminating or neutralization of hazards to internal values important for the nation and the state, but also "positive" ones, which precede the coming up of hazards, oriented toward taking up new challenges and positively affecting the certainty of survival, possessing and developmental freedoms of the state and the nation (Zięba, 2005, p. 52).

On the one hand, Poland's membership in NATO and the European Union assures a foundation for our national security. It has a great impact on establishing a favorable international environment of Poland and on strengthening its position among countries of Europe and of the world. On the other hand, it also constitutes a challenge because our country has at its disposal the capacity (and in particular by the military forces of the Republic of Poland) to support member states in emergencies. Respecting fundamental principles of both organizations - solidarity and joint responsibility - led Poland to become an active participant in the European security policy and, to a certain extent, the global one. A stable position of Poland in the international environment boosts our security (Sobolewski, 2020, p. 45).

The concept of Poland's security should be based on joint actions performed together with other entities of the international security environment to maintain peace and individual and collective security. In this respect, Poland would have to face a considerable challenge, consisting of assuring compatibility between the main goals of NATO and objectives adopted by the European Union. Due to expansive changes in hazards and progress in transformations in the international surroundings, NATO and the European Union are undergoing dynamic changes. The military forces of NATO (e.g., NATO Response Forces) and the European Union (EU Battle Groups) as a tool for shaping international security policy are also forced to adapt to new conditions. Active involvement of the Armed Forces of the Republic of Poland in those organizations allows to and boost the potential of the organizations in responding to any hazards to security.

When making analyses of the geopolitical environment in the surroundings of Poland and when developing assumptions for the concept of military security, one should consider possible threats to our country with respect to the Alliance and the European Union. Given specified threat scenarios, there is a need to develop strategic concepts meant to define the ability to counteract and respond. Those concepts should consider the abilities of own

member of the NATO and the European Union - we should be capable of responding to this type of hazard under allied and coalition solidarity. 
military forces, possible support from NATO (or NATO countries), military forces of the European Union, but just as well the specific nature of responding by the North Atlantic Alliance and the European Union, including the time needed to take relevant decisions and launching a military response. It is also necessary to consider our involvement in NATO and the EU operations, implemented beyond the mandate territory of those organizations, and stabilization and peacekeeping operations implemented by the United Nations. Poland (including its military forces) should be capable of reacting to all types of military and non-military threats. The Military Forces of the Republic of Poland should be capable of defending Poland and participating in defending allies, supporting measures meant to stabilize the international environment and bodies of state central and local administration, and assisting the society in the national and international dimension.

An analysis of phenomena presently taking place allows the presumption that causes and symptoms of the generation of military threats would not undergo significant change and would be to a large extent beyond the military region. Naturally, it does not mean that there would be no direct or indirect military threats. It may be presumed that in a time horizon of a dozen or a few dozen years, the present military situation in the surroundings of Europe appears to be impossible to maintain. It could not be ruled out that a factor directly affecting its change could be, among others, the great likelihood that Russia would overcome the economic recession, which will allow it to intensify its efforts at recovering influence in Central and Eastern Europe. A further issue conducive to breaking out of potential conflicts is the breakdown and fall of the existing European integration. United Europe is a strong Europe, while the splitting of the EU considerably weakens military security - particularly the security of smaller states in the European region. For this reason, questions for the nature and essence of contemporary military threats appear to be still valid and justified.

From the military viewpoint, the geographic situation in the central part of Europe, narrowing between the Baltic and the Carpathians, makes the territory of Poland a region of special strategic importance on the European line East-West. Conducted analyses concerning Poland's safety have clearly shown that the fate of our country was affected by geopolitical conditions. For this reason, throughout its history, Poland would give in to military pressure, was an area of unpunished plunder, and, as stated by Clausewitz, a "public road over which foreign troops constantly remained on the prowl". Contemporarily geopolitical conditions allow the presumption that Poland is in a situation in which its southern and western borders should be considered safe from the military viewpoint, while potential hazards may only be expected from the east and north-east. Currently, Poland's eastern border constitutes borders of NATO, the EU, and the Schengen zone, and at the same time, we have borders with Russia, Belarus, and Ukraine. That is why considerable importance is attached to a skillful policy to build good relations as a member of the Alliance and the EU and a directly neighboring country.

We have been a NATO member for more than two decades, and it might seem that as of the moment of becoming a fully-fledged active member of NATO, all concerns concerning 
potential hazards to the security of our state should cease to be valid. Poland's eastern border is also a border of the North Atlantic Alliance and the EU, which may expose our country to the impact of potential opponents of the Alliance or Western Europe. When assessing the threats, it is necessary to take into consideration the existing conditions and the current geostrategic situation, which comprise primarily the following:

- first - the possibility of forming a new balance of power on the eastern border of Poland, for example, as a result of joining forces of Russia and Belarus, unstable situation of Ukraine or developing cooperation of Russia with China;

- second - dynamics of changes in the political intent in neighboring countries as to the deployment of armed forces, and in particular the present and the anticipated (within a specified time horizon) ability of the armed forces concerning the execution of armed actions;

- third - Poland's belonging and position in the security balance system (coalition, alliance) as a guarantee of security;

- fourth - current relations of Poland with the international surroundings, the international standing, strategic areas of political, economic, and military cooperation;

- fifth - own potential of our country and its defense capabilities (especially the potential and quality of the Military Forces of the Republic of Poland), level of defense readiness.

Given its national identity, based on historical experiences and modern needs, the Republic of Poland considers that one of the elementary values that reflect the most important national interests, under the Constitution of the Republic of Poland, is that military security is an ability to assure independence and inviolability of its territory. As a country with an adopted military doctrine, Poland can prepare in advance and use forces, means, and methods of military actions that would assure effective opposition to aggression of an opponent's overwhelming forces. It is possible thanks to strengths arising from the defense of own territory and the natural advantage of defense from attack (Clausewitz, 2010, p. 28). Forces that may be effectively used in defense of the state include, for example, the Military Forces of the Republic of Poland (including also the widely understood system of territorial defense), forces of countries belonging to the North Atlantic Alliance, non-military defense entities, and widely understood state defense preparation.

The current legal regulations foresee a situation in which Poland may find itself in a state of war only due to aggression oriented at it or an allied country. Depending on the scale of the aggression and magnitude of military operations, this may be a large-scale war involving the entire state over a longer period or a local armed conflict - limited to the involved forces, time, and space. For Poland as a NATO member, each war, regardless of the scale, would be one taking place in an alliance agreement - according to the principle that each aggression toward a NATO member, including also against Poland, is, in fact, aggression against the whole NATO. Poland considers the possibility of military aggression and the emergence of a military conflict in defense of its territory (repelling direct aggression on the territory of 


\section{Wschodnia flanka NATO}

W Polsce, Litwie, Łotwie i Estonii stacjonują Międzynarodowe Bataliony NATO. Obecność wojsk sojuszniczych jest rotacyjna, pod dowództwem oddziałów USA, Wielkiej Brytanii, Niemiec i Kanady.

\section{ROZMIESZCZENIE MIĘDZYNARODOWYCH BATALIONÓW NATO}

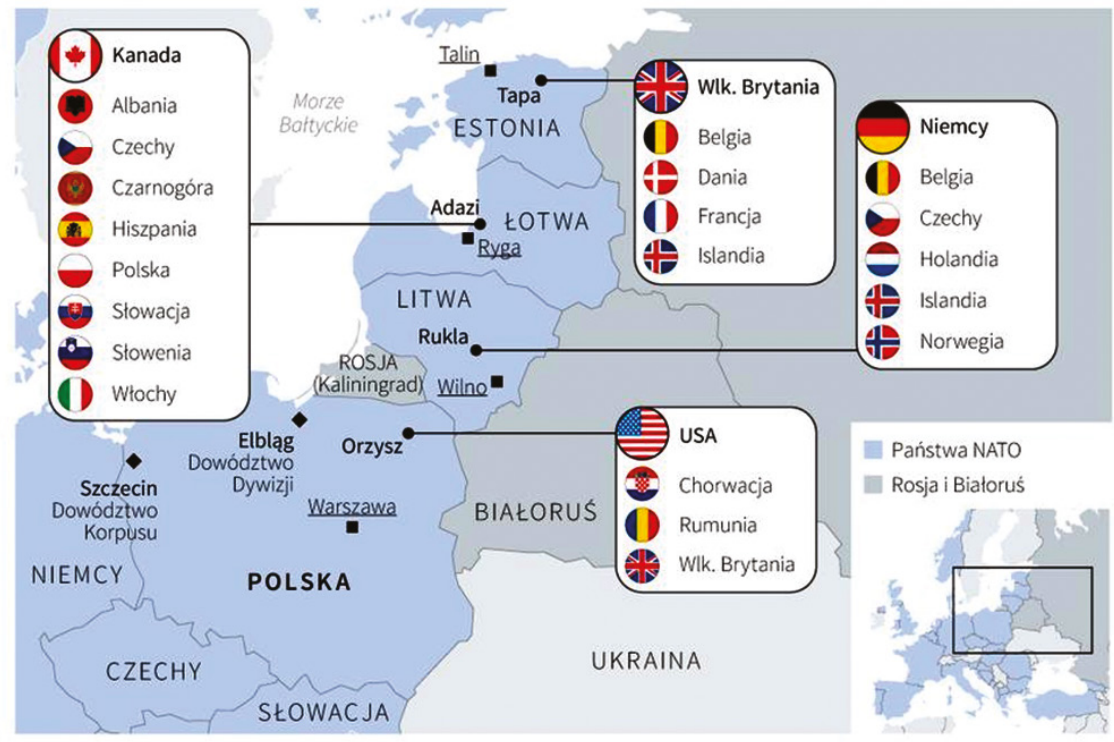

Żródło: NATO, stan na 23 kwietnia 2019 r.

Fig. 3. Forces of the NATO Alliance on the eastern flank of NATO Source: https://archiwum2019.mon.gov.pl/sily-sojusznicze-w-polsce

Poland) and in an armed conflict beyond its territory (involvement in repelling aggression directed against an allied country). Poland would need to bear the most significant load and effort during the defense war on its territory. Consequently, taking into account the border situation of Poland in the NATO region, the Armed Forces of the Republic of Poland, as those forming the first strategic echelon of the Alliance, should be capable of immediately responding to each transgression of the territory of the Republic of Poland, and in the first place to protect from air and rocket strikes.

It is clear that the presence of military services of the Alliance and the US army (fig. 3) and the Alliance's concepts of increased presence on the "eastern flank of NATO" strengthen the military security of Poland in a measurable way as well as that of the Baltic states (Lithuania, Latvia, and Estonia) ${ }^{8}$.

${ }^{8}$ As many as $67 \%$ of the respondents are convinced that troops of other NATO countries be stationed 
If a potential opponent decided to commence direct military aggression, it would also commit aggression toward other countries and their military units stationing on the territory of NATO countries in Eastern Europe. Moreover, during the NATO summit in Brussels and afterward in 2019 in London, an additional element was established to strengthen the security of the NATO eastern flank area by NATO Readiness Initiatives or "Four Thirties". According to it, the Alliance has at its disposal 30 mechanized battalions, 30 air squadrons, and 30 battleships ready to take up operation within 30 days or less. It is all the more important as in case of military aggression on our country, the first to take up actions would be Poland's military forces, forces of the Alliance stationing on the territory of Poland, and elements of immediate NATO reinforcement, the so-called "Spearhead Force" (VJTF, i.e., Very High Readiness Joint Task Force), capable of becoming deployed during one week. Next (i.e., up to 30 days), forces of the "Four Thirties" would be deployed for action and further NATO strengthening forces in line with allied operating plans.

Consequently, all defense actions, both within a local military conflict and in case of a large-scale war, would right from the start be of allied type. In case of a local armed conflict, the goal is to counter aggression as quickly as possible and to crush the opponent's troops by forces at disposal already in the period of peace - even considering limited involvement of allied forces, also for objective reasons. It requires a considerable potential of response forces at disposal, capable and ready to be deployed quickly to defend Poland's territory. Should the conflict become prolonged, own additional forces would be involved, expanded as a result of mobilization, and additional allied forces indispensable to allow its ultimate resolving.

In case of a large-scale war, the structure of the defense potential would be made up by national forces, forces of the Alliance stationed permanently, and further NATO forces developed on our territory in a period of intensification of the crisis and operating according to jointly developed allied operating plans. In case of a large-scale war, the defense strategy assumes coordinated use of the national defense potential, including deploying on the territory of Poland of relevant allied reinforcement forces to prevent the loss of the territory and achieve the quickest possible crushing of the aggressor. Such destruction of its war potential was to render impossible undertaking a new attempt at aggression - with the concurrent assurance of maximum protection of own population and national property from potential losses and destructions.

Changes in conditions in the European and global security environment give rise to the necessity of searching for new solutions concerning efficient responding to any hazards that might appear. There is a need for military, national, and allied forces capable of quick and effective countering the opponent's actions. The observed dynamic nature of political and military changes requires constant adaptation to new situations concerning conceptual solutions and the decision-making procedures of organizations entrusted with security

in Poland, and 24\% of them supports this in a determined way, and 43\% moderately. Survey of 2018, https:// www.gov.pl/web/obrona-narodowa/polacy-popieraja-obecnosc-wojsk-nato-w-polsce 
issues. Such conduct is consistent with the Roman principle "si vis pacem, para bellum" (if you want peace, get ready for war). If we want to counteract war, we have to be familiar with its mechanisms.

\section{Recapitulation}

In the $21^{\text {st }}$ century, we are witnessing significant transformations that are taking place in the phenomenon of war as such. A characteristic feature of contemporary military threats is the mutual permeation of military and non-military hazards. If a country attacks another by conventional forces (land, sea, or air forces), it is, as a rule, quite obvious how to react. We have at disposal appropriate scenarios for such situations. Nevertheless, the answer is not simple because it is not easy to identify the object area and forms of impact. A thesis may even be formulated that contemporary hazards are of a hybrid and asymmetric nature when use is made of various entities, methods, and forms necessary to overcome the opponent and achieve political and military objectives. Currently, the possibility of accurate identification of entities being sources of hazards (state, organization, or social group) is limited - much more importance is given to conditions and factors that generate potential threats and areas of their occurrence. The situation is similar to methods and forms in the case of the occurrence of episodes of non-military actions, terrorism, and typical non-military actions. The aggressor strictly controls the intensity, nature, and impact area to conduct the conflict below the war threshold. Asymmetric actions, hybrid actions of the opponent are meant to make it impossible to identify the state of war and the entity being the aggressor. The achievement of such a state gives rise to difficulties in adopting a clear standpoint by organizations such as the UN, NATO, and the EU, which frequently causes a lack of reaction of the international community.

Anticipated assumptions of military security policy in conditions of membership in NATO and the European Union within the time horizon of the next few years should, first of all, comprise enhancing alliance solidarity, Poland's position and role in NATO and the European Union by active involvement in NATO operations, as well as operating to assure cohesion and effectiveness of the Joint Security and Defense Policy of the European Union, which should be compatible with the strategic concept of NATO. Poland's functioning within structures of the North Atlantic Alliance and the European Union is perceived as a guarantee of state security, but at the same time gives rise to the possibility of multidimensional development and growth of the role of our country, and is also conducive to strengthening Poland's position on the international arena and impact on the international environment. Participation of Poland in a collective security system and building good relations with the neighboring countries provide opportunities for the Polish security strategy and should consequently be perceived as its priority. Implementation of the assumption will only be possible if the defense and protection potential is achieved appropriately to the needs and possibilities of the state and enhancing its compatibility with the potential of allies and 
partners from NATO and the European Union. At the same time, this would allow taking up actions to ensure effective defense both in the national and allied systems. There is also a need for actions aimed at consolidation, cooperation, and further expansion of both organizations, further enhancing European integration concurrently maintaining the identity of national states. Furthermore, the constant development of international cooperation and supporting allied and European aspirations of candidate countries should also be considered a fundamental assumption of our policy.

\section{References:}

Balcerowicz, B. (1997). Obronność państwa średniego. Warsaw.

Balcerowicz, B. (2002). Pokój i “nie-pokój” na progu XXI wieku. Bellona.

Balcerowicz, B. (2010). Sity zbrojne w stanie pokoju, kryzysu, wojny. Scholar.

Balcerowicz, B. (n.d.). Bezpieczeństwo militarne,p.3.https://pracownik.kul.pl/files/110288/public/b._balcerowicz_-_bezpieczenstwo_militarne.pdf

BBN. (2012). Bezpieczeństwo Narodowe, 23-24.

Biała księga bezpieczeństwa narodowego RP. (2013). Warsaw.

Brzeziński, Z. (2002). O Polsce, Europie i świecie 1988-2001. Bellona.

Budzkowski, K. (2010). Międzynarodowe wyzwania bezpieczeństwa. Kraków.

Clausewitz, C. (2010). O wojnie. Mireki.

Gawliczek, P., \& Pawłowski, J. (2003). Zagrożenia asymetryczne. AON.

Kitler,W. (2011). Bezpieczeństwo narodowe RP. Podstawowe kategorie, uwarunkowania, system. AON.

Kitler, W. (2018). Organizacja systemu bezpieczeństwa narodowego RP. Wydawnictwo Adam Marszałek. Koziej, S. (2008). Między piekłem a rajem. Szare bezpieczeństwo na progu XXI wieku. Wydawnictwo Adam Marszałek.

Kuliczkowski, M., \& Sawicki, L. (2020). Pozamilitarne przygotowania obronne w Polsce. ASzWoj.

Madej, M. (2007).Zagrożenia asymetryczne bezpieczeństwa państw obszaru transatlantyckiego. PISM. Majchrzak, D. (2015). Bezpieczeństwo militarne Polski. AON.

Marszałek-Kawa, J., \& Plecka, D. (2017). Social Security as a Factor Contributing to the Evolution of the Political System in Poland after the Parliamentary Elections of 2015. Środkowoeuropejskie Studia Polityczne, 4, 79-94.

Marszałek-Kawa, J., \& Plecka, D. (Eds.) (2019). The Dictionary of Political Knowledge. Wydawnictwo Adam Marszałek.

Marszałek-Kawa, J., Ratke-Majewska, A., Wawrzyński, P. (2014). Konstytucja a nowa tożsamość polityczna w tranzycji demokratycznej. In R. Alberski, W. Jednaka, D. Skrzypiński (Eds.), Studia nad wspótczesnymi systemami politycznymi, vol. 2, Instytucje i mechanizmy rywalizacji politycznej. Ksiega dedykowana Profesorowi Andrzejowi Antoszewskiemu (pp 154-166). Wydawnictwo Adam Marszałek.

Pawłowski, J., Zdrodowski, B., \& Kuliczkowski, M. (2020). Słownik terminów z zakresu bezpieczeństwa. Wydawnictwo Adam Marszałek.

Sobolewski, G. (2020). Sity Zbrojne RP w systemie bezpieczeństwa państwa. Warsaw.

Targowski, A. (1993). Obrona Polski dziś i jutro. Bellona.

Zięba, R. (2005). Wstęp do teorii polityki zagranicznej państwa. Wydawnictwo Adam Marszałek. 
Constitution of the Republic of Poland of 2 April 1997, Official Journal of Laws/Dz.U. 1997, No. 78, item 483.

Strategy of National Security of the Republic of Poland. (2020). Warsaw.

Development strategy of the national security system of the Republic of Poland 2012-2022. (2013).

Warsaw.

http://www.aco.nato.int

http://www.bbn.gov.pl

http://www.eur-lex.europa.eu

http://www.europolityka.pl

http://www.jftc.nato.int

http://www.politykaglobalna.pl

http://www.polska-zbrojna.pl

https://www.defence24.pl

https://www.globalfirepower.com

https://www.gov.pl

https://www.wojsko-polskie.pl 